This article was downloaded by: [OARE Consortium]

On: 04 July 2015, At: 04:17

Publisher: Taylor \& Francis

Informa Ltd Registered in England and Wales

Registered Number: 1072954 Registered office: 5

Howick Place, London, SW1P IWG

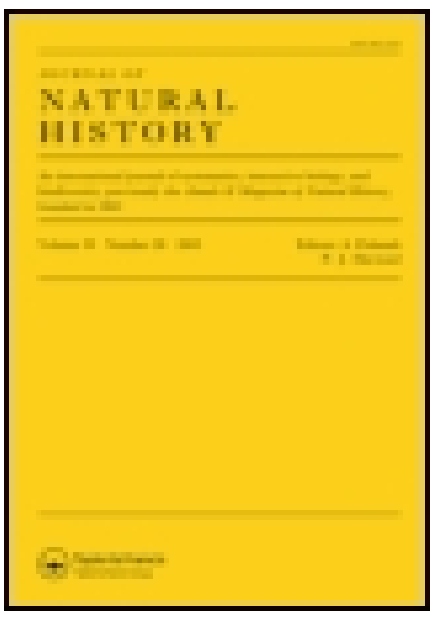

Annals and Magazine of Natural History: Series 1

Publication details, including instructions for authors and subscription information: http:// www. tandfonline.com/loi/ tnah07

\title{
Habits of the blue titmouse
} (Parus cæruleus)

\author{
M. Hill ${ }^{a}$ \\ ${ }^{\text {a }}$ Rowmore \\ Published online: $15 \mathrm{Mar}$ \\ 2010.
}

To cite this article: M. Hill (1838) Habits of the blue titmouse (Parus cæruleus), Annals and Magazine of Natural History: Series 1, 1:2, 158-159, DOI: 10.1080/00222933809512259

To link to this article: http://

dx. doi.org/ 10.1080/00222933809512259 
Taylor \& Francis makes every effort to ensure the accuracy of all the information (the "Content")

contained in the publications on our platform. However, Taylor \& Francis, our agents, and our licensors make no representations or warranties whatsoever as to the accuracy, completeness, or suitability for any purpose of the Content. Any opinions and views expressed in this publication are the opinions and views of the authors, and are not the views of or endorsed by Taylor $\&$ Francis. The accuracy of the Content should not be relied upon and should be independently verified with primary sources of information. Taylor and Francis shall not be liable for any losses, actions, claims, proceedings, demands, costs, expenses, damages, and other liabilities whatsoever or howsoever caused arising directly or indirectly in connection with, in relation to or arising out of the use of the Content.

This article may be used for research, teaching, and private study purposes. Any substantial or systematic reproduction, redistribution, reselling, loan, sublicensing, systematic supply, or distribution in any form to anyone is expressly forbidden. Terms \& Conditions of access and use can be found at http:// www.tandfonline.com/page/terms-and-conditions 
same month. The date when the first specimen was procured here is unknown.

The Woodcock (Scolopax rusticola) breeding in Ireland.-Within the last few years these birds have bred in several of the Irish counties, including northern, central, and southern. The details on this subject, as well as on the spotted redshank and night heron, are reserved for their due place in my intended series of papers on the Birds of Ireland, of which three have already appeared in the second volume of the Magazine of Zoology and Botany, and one in the first number of this work.-W. Tномpson, Belfast, March 1838.

\section{FOSSIL SALAMANDER AND COPROLITE.}

In a Letter from M. de Paravey to the French Academy, the writer states that he saw at Leyden, in the cabinet of M. van Breda, the fossil skeleton of a salamander, about three feet long, and in a more perfect state than that figured by Scheuchzer in his Homo di. luvii testis. What increases the value of this specimen is that it contains in the part corresponding to the abdomen several coprolites, in which we detect fragments of the bones of frogs and of eels, \&c., so that we have proof that the antediluvian species had the same kind of food as the larger salamanders of the present day. A very large salamander, brought by $M$. Siebold from Japan, is still living at the Leyden Museum, and is fed chiefly with frogs. This celebrated traveller brought to Europe the male and female, but the latter was one day devoured by its companion, which no doubt had been kept too long without food.-Comptes Rendus, Nov. 19, 1838.

\section{HABITS OF THE BLOE TITMOUSE (Ṕarus coruleus).}

A redstart ( , hocnicura ruticilla, ) and a blue titmouse built nests in an old wall within a few feet of my parlour window. The nests were placed within three feet of each other; that of the redstart in a very open rent, while that of the titmouse was better secured by having a very small entrance, as is usually the case with the situations chosen by this bird. My attention was at first attracted by the violence with which I frequently saw the titmouse drive away both the parent redstarts when approaching their own nest with food for their young; and, knowing the pugnacious disposition of the titmouse, I at first thought that it wished to destroy its neighbours, as after chasing them to a little distance it would fly into the redstart's nest. As the redstart was to me the rarest bird, I began to debate with myself whether I should not destroy the titmouse, that the other might not be prevented from bringing up its young. In the 
course of doing so, and observing the attacks I have described frequently repeated, I was at last astonished to find that the object of the titmouse was actually to feed the young redstarts together with its own. I spent many an hour in watching this, and have seen that when both parents arrived at the same time with caterpillars in their bills, the titmouse would fiercely drive the redstart away and give the caterpillar to its young. In this way did the titmouse indiscriminately feed the young in both nests, while the redstart never attempted such a reciprocation of favour; but when arriving with food for its own young, would wait on a neighbouring branch till the old titmice left their nest.-M. HiLr, Rowmore.

\section{ZOOLOGICAL GARDEN IN EDINBURGH.}

For several years there has been an endeavour to establish a Zoological Garden in Edinburgh. Mr. Wombwell made offers at one time, and Sir Thomas Dick Lander has often used his interest for the same purpose. The great want has hitherto been the difficulty of getting some active person as a general superintendent; and Mr. Douglas, who has for several years imported for sale a considerable selection of foreign birds, has expressed his willingness to undertake the charge, and to embark a portion of his own capital in the undertaking. Several influential gentlemen in Edinburgh and its vicinity have been spoken with, and have expressed their anxiety to support the Garden. A piece of ground at the west end of the town, on the property of Coates, has been examined, and could it be obtained would be a most suitable site, being free from damp, and at the same time affording facilities for artificial waters. When the plans are more matured we shall report progress, and in the mean time will hope that the Societies already prosperous will contribute to the advancement of one about to be commenced.

TWEEDSIDE PHYSICAL AND ANTIQUARIAN SOCIETY.

This Society, only established in 1834 , has advanced most rapidly. Its collections have increased so greatly that more accommodation is now required; and at a late meeting it has been resolved to build a museum in Kelso. For this purpose the gentlemen in the vicinity have subscribed liberally; while the society of gentlemen educated at Kelso Grammar School have given the sum of $200 l$. to aid in its erection. We are induced to make this short notice to show the advance which Natural Science is making north of the Border; and as the first instance, we believe, where a provincial Society in Scotland has ventured to erect a Museum, for the purpose alone of accommodation for its meetings and the preservation of its collections. 